\title{
ОРГАНІЗАЦІЯ САМОСТІЙНОЇ РОБОТИ СТУДЕНТІВ ПРИ ВИВЧЕННІ ПРЕДМЕТА “СЕСТРИНСЬКА ПРАКТИКА”
}

\author{
ДВНЗ “Івано-Франківський національний медичний університет”
INDEPENDENT STUDENTS' WORK ORGANIZATION DURING STUDYING THE SUBJECT “NURSING PRACTICE”

Н. В. Зозуляк

N. V. Zozuliak

\author{
Ivano-Frankivsk National Medical University
}

\begin{abstract}
Студенти 3 курсу вищих медичних закладів вивчають важливий для кожного практичного лікаря предмет “Сестринська практика”. Після опанування даного предмета студент має оволодіти вмінням виконувати різноманітні медичні маніпуляції. У зв'язку з реорганізацією навчальної програми великий обсяг матеріалу відведено на самостійне вивчення. Для кращого засвоєння матеріалу студентам запропоновано використовувати такий алгоритм: самостійна підготовка вдома, використовуючи рекомендовану літературу та відео з інтернету, а також відвідування навчальних баз кафедри. У результаті предмет засвоюється набагато ефективніше, а заняття проходить цікавіше для студентів.
\end{abstract}

3rd year students of the higher medical institutions study important for each practical doctor subject "Nursing Practice". After finishing the subject student becomes able to perform various medical procedures. Due to reorganization of the training program a large amount of material is devoted to independent study. For better learning, students are asked to use the following algorithm: self-training at home using the recommended books and videos from the Internet and visit training bases of the department. As a result, the subject is learned by students much more efficiently, and classes are interesting for students.

Вступ. Студенти 3 курсу вищих медичних закладів вивчають важливий для кожного практичного лікаря предмет “Сестринська практика”. На заняттях студенти знайомляться з основними засадами медсестринства в Україні, організацією роботи молодшого медичного персоналу в терапевтичному стаціонарі i, звичайно, виконанням основних маніпуляцій - різних видів ін'єкцій, клізм, промивання шлунка, основних фізіотерапевтичних процедур.

Кожен майбутній лікар, безперечно, повинен володіти навиками виконання усіх видів ін'єкцій. Часто саме ці навики можуть врятувати життя пацієнту, адже у випадку анафілактичного шоку чи клінічної смерті хвилини i, навіть, секунди зволікання можуть коштувати людині життя. Окрім того, згідно із законодавством України, у разі неможливості виконання ін'єкції медсестрою, лікар зобов'язаний виконати дану маніпуляцію. Саме тому кваліфікована підготовка майбутніх медичних працівників $€$ настільки важливою $[1,2]$.

Основна частина. У зв'язку з реорганізацією навчальної програми з предмета “Сестринська

(c) Н. В. Зозуляк практика”, великий обсяг матеріалу відведено на самостійне вивчення. Практичних занять з даного предмета передбачено тільки 4, тобто 8 год. Ще 2 год відводяться на модульний контроль. На самостійну роботу виносять 30 год. Оскільки специфіка виконання практичних навиків унеможливлює самостійну підготовку студентів вдома, необхідно забезпечити належне засвоєння матеріалу. Звичайно, існує величезна кількість теоретичного матеріалу, який у достатній кількості представлений у бібліотеці ІФНМУ. Окрім того, у мережі “Інтернет” доступними $€$ відео з алгоритмом виконання різноманітних маніпуляцій. Проте загальновідомим $€$ факт, що якщо студент виконає самостійно певну ін'єкцію, у нього назавжди у пам'яті залишиться алгоритм виконання даної процедури, яку лікар зможе виконати у майбутньому за будь-яких умов: чи то критичний випадок під час нічного чергування, а чи неможливість “знайти вену” в ін'єкційного наркомана [3, 4].

Враховуючи вищеописані факти, кафедра пропедевтики внутрішньої медицини пропонує студентам такий алгоритм виконання самостійної роботи 
при підготовці до практичних занять із предмета “Сестринська практика”:

1. Самостійна підготовка студентами на основі рекомендованої літератури (список літератури вказаний у методичних рекомендаціях).

2. Перегляд відеоматеріалів у мережі “Інтернет”.

3. Відвідування студентами навчальних баз ІФНМУ.

Навчальними базами кафедри пропедевтики внутрішньої медицини є терапевтичне відділення № 2 Центральної міської клінічної лікарні м. Івано-Франківська, а також Університетська клініка ДВНЗ “Івано-Франківський національний медичний університет”.

Студентам пропонується у вільний позааудиторний час відвідувати дані бази, де медсестри люб’язно допоможуть їм у виконанні даних маніпуляцій. Молодший медичний персонал присутній у

\section{Список літератури}

1. Захарченко Т. Роль наочності у процесі викладання професійно орієнтованих дисциплін / Т. Захарченко // Вища школа. - 2013. - № 12. - С. 30-38.

2. Касевич Н. М. Основи медсестринства в модулях / Н. М. Касевич - К. : Медицина, 2013. - 478 с. лікарні та готовий допомогти 24 год на день, 7 днів на тиждень. Проте найоптимальнішим є варіант, коли студенти приходять у вихідні дні. Саме тоді $є$ можливість самостійного виконання студентами багатьох маніпуляцій.

Висновки. Медична наука не стоїть на місці. Кожен день, навіть кожну годину відбуваються нові відкриття. Раціональному лікарю важливо відслідковувати та вводити у практику нововведення. Саме тому медична самоосвіта є надзвичайно комплексним та складним процесом. Загальновідомим є той факт, що навчання лікаря відбувається усе життя і переважну більшість цього навчання свідомий медичний працівник опрацьовує самостійно. Завдання медичного вузу, на нашу думку, полягає не тільки у підготовці кваліфікованих кадрів, а у закладанні основ, приживанні навичок майбутнього лікаря до якісної самоосвіти.

3. Психологія і педагогіка : підручник для студентів ВНЗ / за ред. С. Д. Максименка. - Вінниця : Нова книга, 2007. - 367 с.

4. Ясько Б. А. Психология личности и труда врача : учеб. пособ. / Б. А. Ясько. - Ростов н/Д : Феникс, 2005. -250 c. 